\title{
Growing Role of Bancassurance in Banking Sector
}

\author{
Rebeena Alavudeen and Dr. Sr. Rosa K.D
}

\begin{abstract}
The growing global insurance industry has brought new channels of distribution into existence, leading to a new concept called Bancassurance. Nowadays banks have started increasing their business to securities and insurance and other sectors by adding new range of products. Bancassurance, one such concept, has gained recognition in the recent years. The growth of bancassurance depends on how well banks and insurance companies are able to conquer the operational challenges that are frequently thrown at them. Banks aims at a comprehensive Bancassurance Management with Core Banking platform ie; ease of premium payments using Auto Debit Cards, Net Banking, collection agencies etc. The present empirical based study was conducted with an objective to examine the recent trends of bancussurance and to analyse the marketing and distribution channel of insurance, its impact on insurers, customers and banking sector and also to examine the issues and problems of bancussurance. The study was based on both primary and secondary data. The area of study is confined only to selected banks of Trissur district. The collected data is analyzed and interpreted by applying various statistical tools and techniques. It is presented in the form of tables, pie diagram and bar diagrams. The research findings will be useful for all the three segments including banks, insurers and customers. The paper concludes that there is a bright future for bancassurance in the Indian insurance market.
\end{abstract}

Keywords--- Bancassurance, Insurance Company, Recent Trends, Banking Sector, Insurers, Customers

\section{INTRODUCTION}

$\mathrm{T}$ HE banking and insurance industries have developed rapidly in the changing and challenging economic environment all over the world. Due to merging of global financial markets, development of new technologies, universalization of banking industries and with the expansion of non-banking activities, the insurance industry has globally brought in new channels of distribution into existence.

This has given rise to a new form of business wherein two big financial institutions have come together and have integrated all their strength and efforts to generate new means of marketing for encouraging their products and services.

Rebeena Alavudeen, Research Scholar, Research and PG Department of Commerce and Management Studies, St. Joseph's College, Irinjalakuda680121,E-mail:rebinaabid@gmail.com

Dr. Sr. Rosa. K.D, Associate Professor and Research Guide, Research and PG Department of Commerce and Management Studies, St. Joseph's College, Irinjalakuda-680121.E-mail:srrosebastin@gmail.com

DOI: 10.9756/BIJIEMS.8016
When these two join together it gives birth to "BANCASSURANCE".

Bancassurance is the allocation of insurance products through the huge network of banks whereby, banks act as a distribution channel for providing varieties of banking and investment products and services.

According to Insurance Regulatory and Development Authority (IRDA), "Bancassurance refers to banks acting as corporate agents for insurers to distribute insurance products".

Bancassurance offers many advantages to banks, insurers and the customers. For the banks, income from Bancassurance is the only non-interest based income. The insurance company gets better geographical reach without additional costs. Providing multiple services at one place to the customers improves customer satisfaction.

\section{REVIEW OF LITERATURE}

The article titled "An Evaluation of Distribution Channels in Life Insurance: Agents vs. Bancassurance” by Mekala Mary Selwyn examines critically the shortcomings of a typical life insurance agent in India and compares it with the operation of bancassurance.

"Bancassurance: Challenges and Opportunities in India", Rachana Parihar, the author, brings out as to how bancassurance will be beneficial to banks, insurers and customers. The author takes a bird's eye view of the global scenario of bancassurance. He discusses the distribution channels and the cultural issues involved in distribution and presents the challenges and opportunities of bancassurance in India.

This article has a value addition "Bancassurance - Indian Scenario" by Sharath Jutur. The author argues that bancassurance in India is still in its nascent stage and has to go a long way overcoming many challenges along the way.

"Europe and Bancassurance: A Work in Progress", by Richard Reed explains the differences between one European Country (EU) and another on the success of bancassurance as a distribution channel for life insurance products. The author identifies the broad factors that act as business drivers from country to country and discusses the critical success factors for bancassurance models. It is further stated that bancassurance is forecast to gain market share across Europe, even in countries such as Spain, where it already dominates the market.

"Bancassurance in India - An Emerging Concept", by V.V Ravi Kumar highlights the increasing importance of cross-selling in financial services sector. Banks are also inclined to leverage their vast distribution networks to augment their non-interest income. Bancassurance with its origins in France is also an important component of such an 
effort in view of the added thrust on retail. With only about a quarter of the insurable population covered under insurance, insurers see a great potential in bancassurance as it offers them a readymade distribution platform with a tremendous distribution network. The concept though in its early stages offers immense potential for the future in India.

Dr. Georgee K. 1. Sumi Alex, 2010, "Bancassurance : A Futuristic Convergence". The author discusses the changed equation between banking and insurance businesses under the current circumstances. The author states by concluding that the current situation doesn't indicate any paradigm shift in bancassurance. The future of bancassurance seems to be bright.

\section{STATEMENT OF THE PROBLEM}

Intense competition gave rise to innovative products and new channels of distribution for the marketing of insurance products. The entry of private players in the insurance market resulted in severe competition between the working of public sector and private sector insurance companies in order to capture the market. This work focuses on how Bancassurance is gaining recognition and the role of bank in selling the insurance products. So, the present study is analysing the recent trends of bancassurace, its impact on banking sector, marketing and distribution and the problems of bancassurance.

\section{SCOPE OF THE STUDY}

The present study is about the growing role of bancassurance in banking sector and the selection of samples will be made from amongst the banks having one of the products as insurance.

Many banks and financial institutions have set up joint ventures with insurance companies, but only two banks are selected for the present study.

1. Canara Bank and

2. Housing Development Finance Corporation (HDFC) Bank Ltd.

Although bancassurance business is wide spread over the country, this study is confined to only Trissur District.

\section{OBJECTIVES OF THE STUdY}

Following are the objectives of the study

1. To examine the recent trends of bancassurance.

2. To analyse the impact of bancassurance on insurers, customers and banking sector

3. To study the marketing and distribution channels of insurance products and

4. To examine the issues and problems of bancassurance.

\section{METHOdOLOGY OF THE STUDY}

The study is based on both primary and secondary data as well. The primary data is collected through a well- designed structured questionnaire and discussions with the bank customers. Samples of 80 respondents were identified randomly and through convenience sampling technique the questionnaire was filled by the respondents. Secondary data is collected from various publications, Journals, Insurance Magazines, official websites, Company's annual reports and newspapers. Tables and diagrams have been used at the appropriate places to present and classified the available data.

\section{RECENT TRENDS OF BANCASSURANCE}

1. Bancassurers have not only targeted the mass market but have also carefully begun to segment the market which has resulted in the tailor-made or rather perfect products for each segment.

2. Some bancassurers focus exclusively on distribution. In some markets, face-to-face contact is preferred which proves to be a favorable arrangement for the development of bancassurance business.

3. Initially banks opt for either 'referral models' or 'corporate agency'.

4. Banks are offering space in their own premises to accommodate the insurance staff for selling the insurance products or giving access to their client's database. Insurance companies can use this opportunity to increase their sale.

5. Nowadays banks are campaigning and marketing the insurance products across the globe. Number of banks in India act as 'corporate agents' to insurance company.

\section{DATA ANALYSIS AND INTERPRETATION}

\section{Analysis based on the Impact of Bancassurance on Banking}

\section{Sector}

The performance of both banks and insurance companies' inter-depend on each other. The following study shows the impact of bancassurance on the overall financial performance of banks in India. The figures of Net worth and Net profit reveal that bancassurance has paved the way for banks to grow. Although there are number of other factors which contributed to the growth of banks, but bancassurance is one of the factors.

\section{Canara Bank}

Canara Bank was founded in 1906. The bank was nationalized in 1969. Today, the bank has a network of 3564 branches and 4000 ATMs spread across India.

The bank has tie up arrangements in both life and general insurance through Canara HSBC Oriental Bank of Commerce and United India Insurance Company Ltd. (UIICL) under bancassurance division. It started its Bancassurance business from June 2008.

The following table shows the financial position of Canara Bank and the income derived from bancassurance business. 
Table 1: Financial Position of Canara Bank and Income Derived from its Bancassurance Business (Rs.in Crores)

\begin{tabular}{|c|c|c|c|c|}
\hline Year & Net worth & Net Profit & $\begin{array}{c}\text { Canara HSBC } \\
\text { OBC Life } \\
\text { Insurance Co. } \\
\text { Ltd. }\end{array}$ & $\begin{array}{c}\text { United India } \\
\text { Insurance } \\
\text { Co. Ltd. }\end{array}$ \\
\hline $2009-10$ & 14,672 & 3,019 & 53 & 8 \\
\hline $2010-11$ & 20,039 & 4,025 & 51 & 11 \\
\hline $2011-12$ & 22,690 & 3,282 & 26 & 12 \\
\hline $2012-13$ & 24,878 & 2,872 & 26 & 13 \\
\hline
\end{tabular}
2013.

Source: Annual reports of Canara Bank from 2009 to

\section{Interpretation}

Table 1 shows that the net worth of Canara Bank for the year 2009-10 was Rs. 14672 crores. It has grown substantially from Rs. 14,672 crores to Rs 20,039 crores in $2010-11$ i.e. an increase of $36.59 \%$. There was a growth of $13.22 \%$ in the year 2011-12 and in the year 2012-13, net worth increased from Rs. 22,690 crores of previous years to Rs. 24,878 crores i.e. registering a growth of $9.64 \%$.

Net profit in the year 2009-10 was Rs. 3,019 crores. It increased by $33.2 \%$ from Rs. 3,019 crores in $2009-10$ to Rs. 4,025 crores of 2010-11. In the year 2011-12 it has reduced by $-18.49 \%$ and earned a profit of Rs. 3,282 crores as compared to previous year's profit of Rs. 4,025 crores. Net profit for the year 2012-13 stood at Rs. 2,872 crores. It reduced by $-12.49 \%$.

Under Bancassurance, Bank earned a huge commission income of Rs. 51 crores for the year 2010-11. During the year 2011-12, income from life insurance business dropped down to Rs. 26 crores from Rs. 51 crores in previous year. In the year 2012-13 the bank recorded a commission income of Rs. 26 crores.

Canara Bank earned a huge commission income of Rs. 8 crores in the year 2009-10 and Rs. 11 crores for the year 2010-11. In the year 2011-12, the bank recorded a commission income of Rs. 12 crores and Rs. 13 crores for the year 2012-13.

\section{Housing Development FINANCE Corporation (HDFC) Bank LTD}

HDFC Bank was incorporated in 1994 by Housing Development Finance Corporation Limited (HDFC), India's largest housing finance company. It was among the first companies to receive an 'in principle' approval from the Reserve Bank of India (RBI) to set up a bank in the private sector.

Under Bancassurance business, HDFC Bank has a joint venture named HDFC Standard Life Insurance Co. Ltd. and HDFC Ergo General Insurance Co. Ltd. HDFC Standard Life Insurance Co. Ltd. was established in the year 2000. It became the first private life insurance company in India. HDFC Ergo General Insurance was established in the year 2002. It is a joint venture between HDFC Ltd and ERGO International AG.

The following table shows the financial position of HDFC Bank and the income derived from bancassurance business.
Table 2: Financial Position of HDFC Bank and Income Derived from its Bancassurance Business (Rs. In Crores)

\begin{tabular}{|c|c|c|c|c|}
\hline Year & Net worth & Net Profit & $\begin{array}{c}\text { HDFC } \\
\text { Standard Life } \\
\text { Insurance Co. } \\
\text { Ltd. }\end{array}$ & $\begin{array}{c}\text { HDFC Ergo } \\
\text { General } \\
\text { Insurance Co. } \\
\text { Ltd. }\end{array}$ \\
\hline $2009-10$ & 21,522 & 2,949 & 534 & 54 \\
\hline $2010-11$ & 25,379 & 3,926 & 670 & 78 \\
\hline $2011-12$ & 29,925 & 5,167 & 456 & 110 \\
\hline $2012-13$ & 36,214 & 6,726 & 472 & 126 \\
\hline
\end{tabular}

Source: Annual Report of HDFC Bank from 2009 to 2013

\section{Interpretation}

Table 2 shows that the the net worth of HDFC Bank for the year 2009-10 was Rs. 21,522 crores. It has grown substantially from Rs. 21,522 crores in 2009-10 to Rs. 25,379 crores in $2010-11$ i.e. an increase of $17.92 \%$. There was a growth of $17.91 \%$ in the year 2011-12 and in the year 2012-13, net worth increased from Rs. 29,925 crores in previous year to Rs. 36,214 crores i.e. registering a growth of $21.02 \%$.

Net profit of HDFC Bank was Rs. 2,949 crores in 2009-10. It increased by $33 \%$ from Rs. 2949 crores in 2009-10 to Rs. 3,926 crores of 2010-11. In the year 2011-12 it has shown a significant growth of $31.6 \%$ and earned a profit of Rs. 5,167 crores as compared to previous year's profit of Rs. 3,926 crores. Net profit of the bank during the year 2012-13 was Rs. 6,726 crores, increased by $30.17 \%$.

Under HDFC Standard Life Insurance Co. Ltd. It earned a huge commission income of Rs. 534 crores in the year 2009-10 and Rs. 670 crores for the year 2010-11. During the year 2011-12, the income from life insurance business decreased significantly to Rs. 456 crores from Rs. 670 crores in previous year. In the year 2012-13 the bank recorded a commission income of Rs. 472 crores.

In the year 2009-10, Under HDFC Ergo General Insurance Co. Ltd., bank's commission income increased to Rs. 54 crores and increased to Rs. 78 crores in the year 2010-11. In the year 2011-12, the bank recorded a commission income of Rs. 110 crores and Rs. 126 crores for the year 2012-13.

\section{Analysis and Interpretation of Primary Data Collected from Customers of the Banks}

The questionnaire has been filled by 80 customers of the 2 selected banks (i.e Canara Bank and HDFC Bank)

The table below shows the respondents profile

Table 3: Respondent's Profile

\begin{tabular}{|c|c|c|}
\hline Gender & Number & Percentage \\
\hline Male & 44 & $55 \%$ \\
\hline Female & 36 & $45 \%$ \\
\hline Total & 80 & 100 \\
\hline
\end{tabular}

Table 3 states that the total sample size of the respondents were 80 , out of which 44 were males and 36 were females.

Table 4: Awareness of Bancassurance among the Customers

\begin{tabular}{|c|c|c|c|}
\hline Awareness & Yes & No & Total \\
\hline No of Users/Total No & 48 & 32 & 80 \\
\hline Percentage & $60 \%$ & $40 \%$ & 100 \\
\hline
\end{tabular}


Table 4 show that, among those who were surveyed, $60 \%$ of the respondents were aware that their banks provide bancassurance. They knew with which insurance company their banks have tie-ups. Also they were aware about various policies provided by their banks. However, $40 \%$ of the respondents were amused with the term bancassurance and didn't know anything about it and the services provided by the banks.

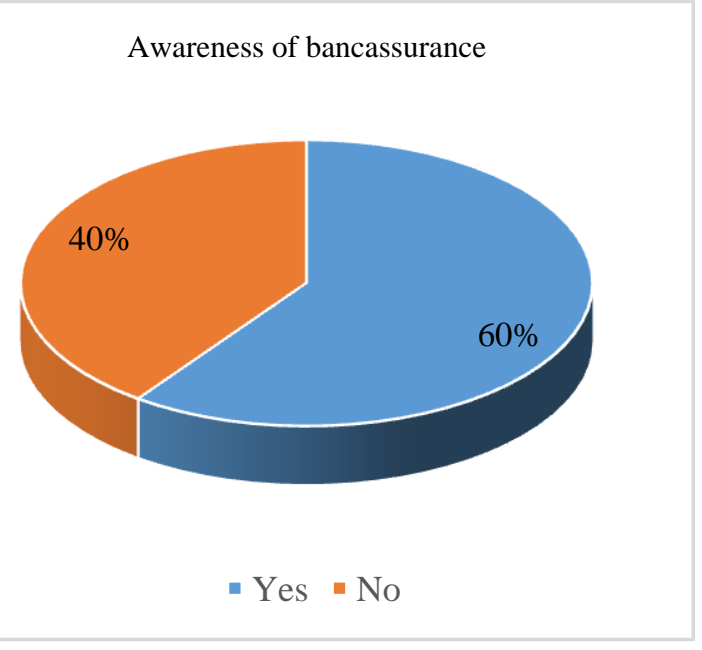

Table 5: Insurance Policy Purchased by the Customers from their Banks

\begin{tabular}{|c|c|c|c|}
\hline Insurance policy taken from banks & Yes & No & Total \\
\hline No of users/Total no. & 55 & 25 & 80 \\
\hline Percentage & $69 \%$ & $31 \%$ & 100 \\
\hline
\end{tabular}

Among the respondents who were surveyed, there were only $69 \%$ people who had taken insurance policy from their respective banks. Remaining 31\% respondents did not opt to take a policy from their banks.

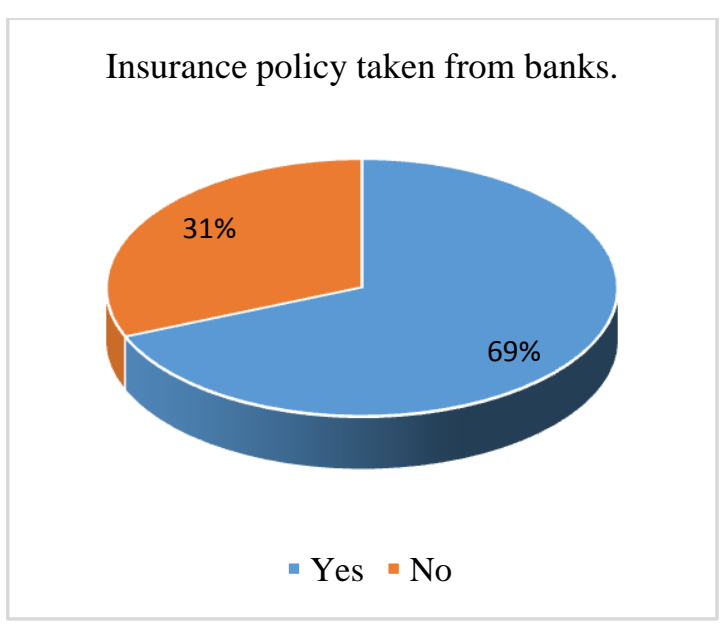

Table 6: Reasons for Buying Insurance Products from Banks Instead of Agents

\begin{tabular}{|c|c|c|}
\hline Reason for taking Insurance from banks & Number & Percentage \\
\hline Personal relationship & 29 & $72 \%$ \\
\hline Trust & 38 & $95 \%$ \\
\hline Convenience & 25 & $63 \%$ \\
\hline Communication & 30 & $75 \%$ \\
\hline Financial soundness & 27 & $68 \%$ \\
\hline Service quality & 35 & $88 \%$ \\
\hline
\end{tabular}

From the above table it is clearly known that the banks are providing the finest service quality and they are maintaining customer relationship management for the bancassurance. 95\% of the customers have trusted their banks. This shows that there is a huge opportunity for bancassurance business in India.

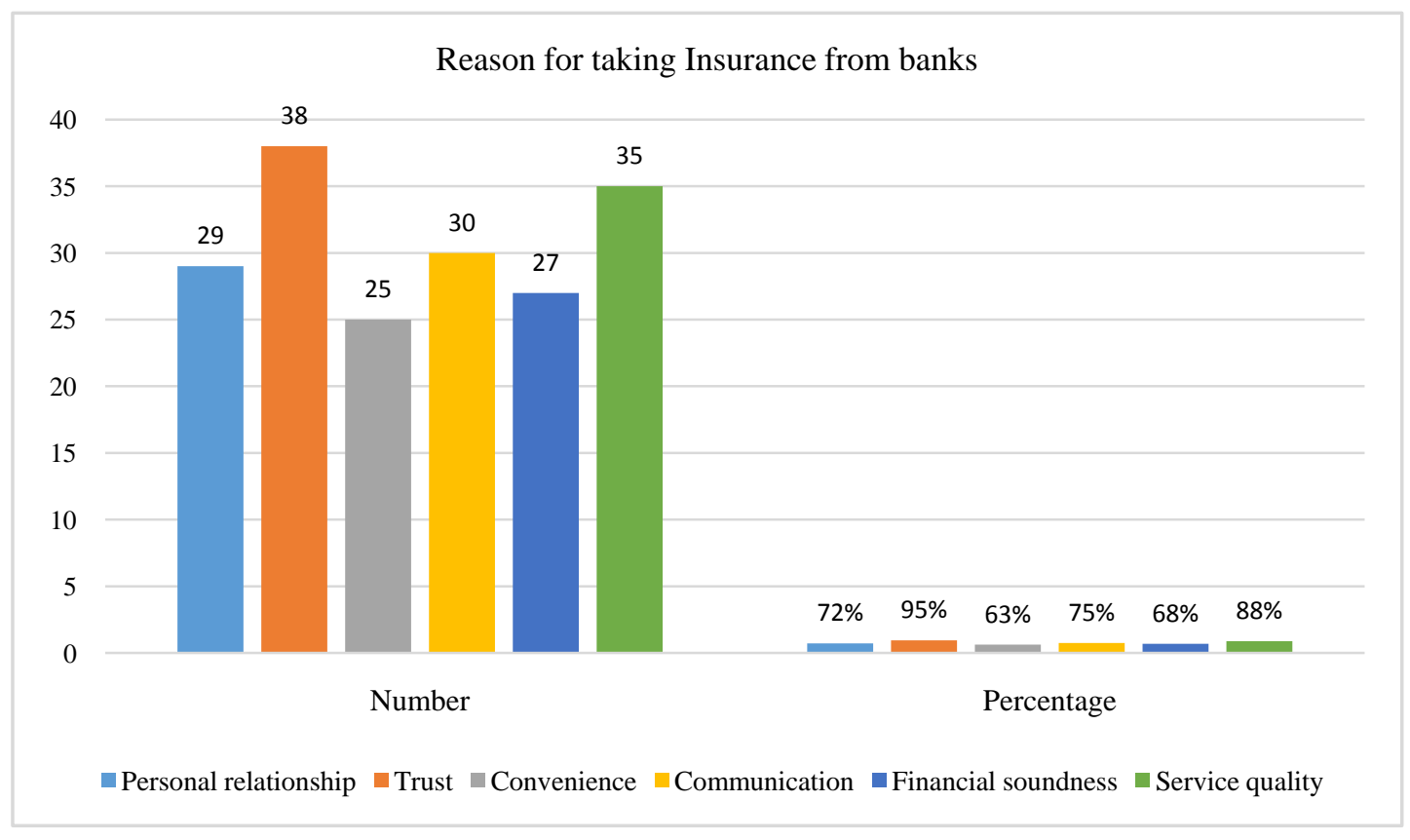


Table 7: Choice of Distribution Channels preferred by the Customers

\begin{tabular}{|c|c|c|c|c|c|}
\hline $\begin{array}{c}\text { Distribution } \\
\text { channel }\end{array}$ & Agents & $\begin{array}{c}\text { Insurance } \\
\text { companies }\end{array}$ & Banks & Brokers & Total \\
\hline $\begin{array}{c}\text { No of users/ } \\
\text { respondents }\end{array}$ & 26 & 24 & 23 & 7 & 80 \\
\hline Percentage & $32 \%$ & $30 \%$ & $29 \%$ & $9 \%$ & 100 \\
\hline
\end{tabular}

From the above table it is observed that $32 \%$ customers preferred agents because they provide personalized services. $30 \%$ took insurance from companies because of their trust on the company. 29\% said they would buy insurance from banks because of the brands name and their trust on banks. Only $9 \%$ said that they would buy insurance from brokers.

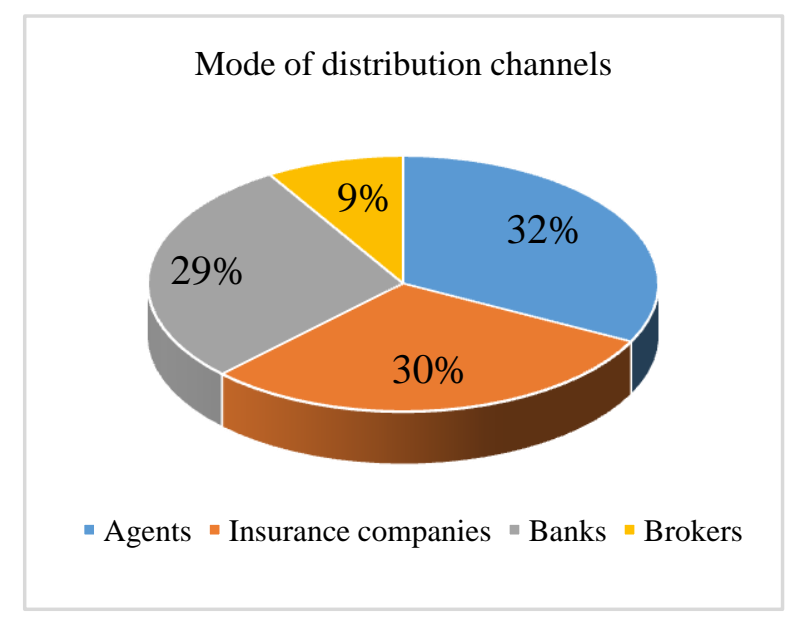

Table 8: Types of Insurance Products taken from the Banks by the Customers

\begin{tabular}{|c|c|c|}
\hline Types of insurance products purchased & Number & Percentage \\
\hline Vehicle insurance & 80 & $100 \%$ \\
\hline Life insurance & 78 & $98 \%$ \\
\hline Health insurance & 65 & $81 \%$ \\
\hline Pension insurance & 36 & $45 \%$ \\
\hline Unit linked insurance & 78 & $98 \%$ \\
\hline
\end{tabular}

It has been observed from the above table that almost all the customers are availing insurance products from the banks. The highest usage rates are for vehicle and life insurance products. This could be one of the facts that vehicle insurance is a chief requirement in India and life insurance offers both security cover as well as tax benefits.

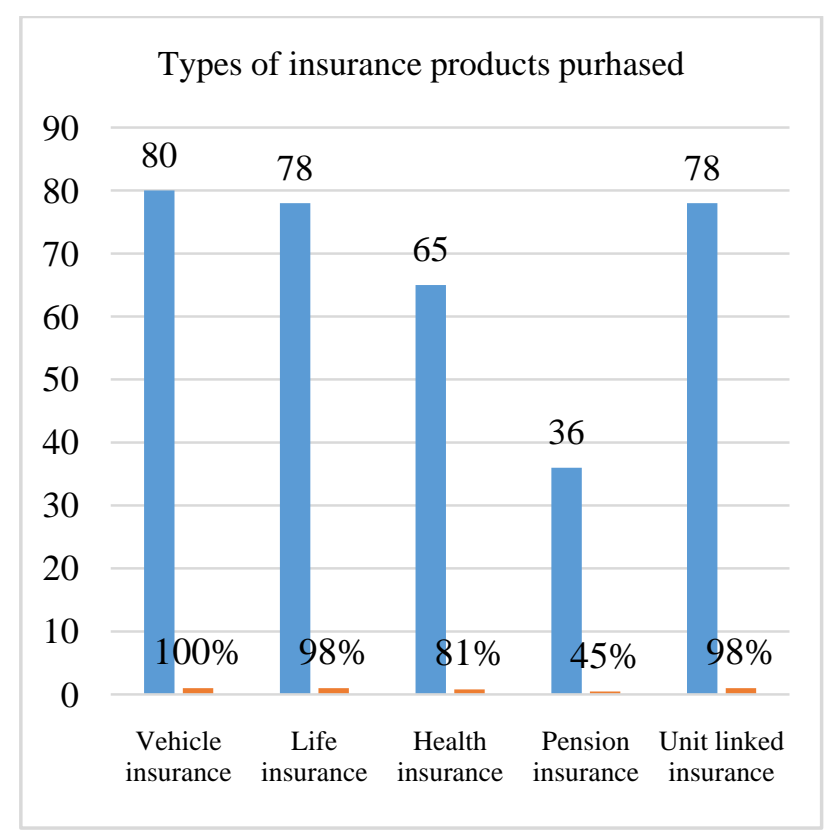

Table 9: Sources of Information regarding Bancassurance

\begin{tabular}{|l|l|l|}
\hline \multicolumn{1}{|c|}{ Source } & Number & Percentage \\
& & \\
\hline Advertisement & 75 & $94 \%$ \\
Bank employees & 62 & $78 \%$ \\
Friends & 65 & $81 \%$ \\
Internet & 58 & $73 \%$ \\
Published materials like brochures etc. & & \\
& 78 & $98 \%$ \\
\hline
\end{tabular}

From the above table it is observed that advertisements are one of the major sources of information for the customers. Better trained bank employees as well as the informative marketing techniques can give boost to the business. The banks that offer bancassurance as one of their products should think of the new media channels which may help the banks to reach out to more customers.

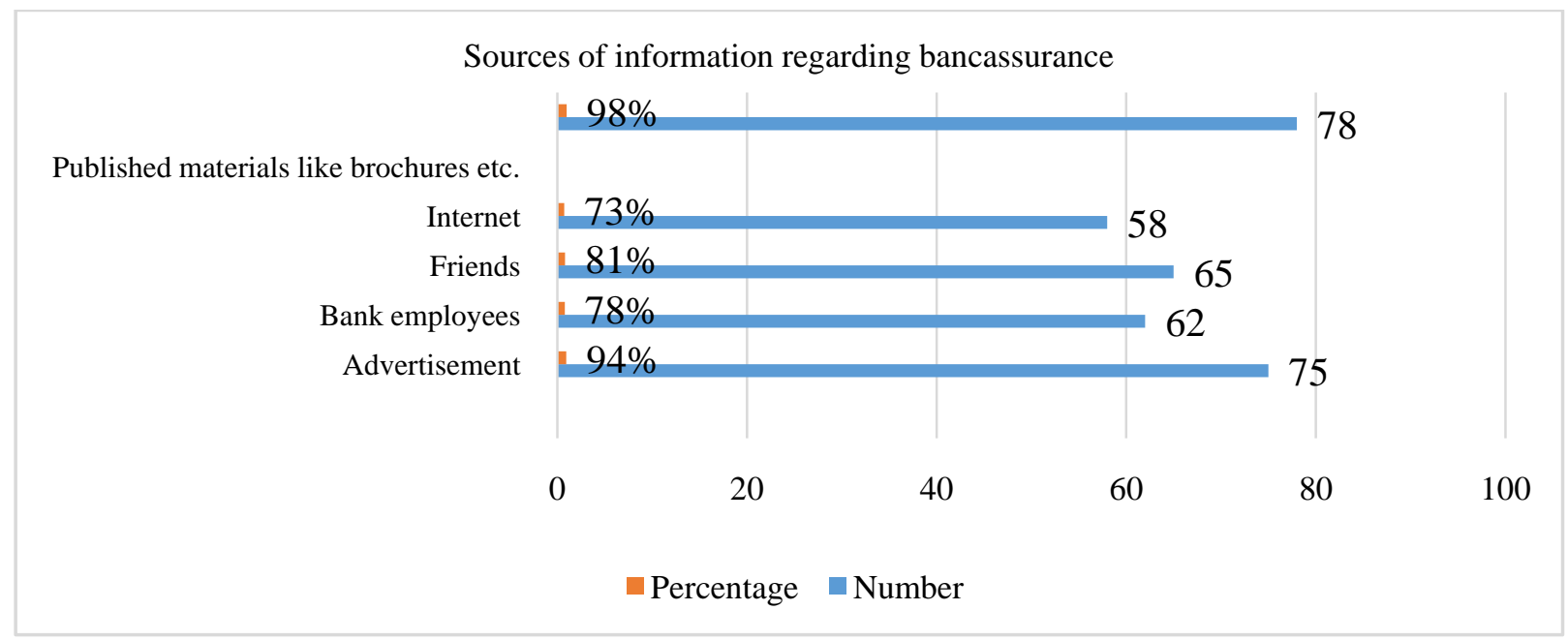


Table 10: Future of Bancassurance in India

\begin{tabular}{|c|c|c|c|}
\hline Future of bancassurance in India & Yes & No & Total \\
\hline No of users/Total no. & 72 & 8 & 80 \\
\hline Percentage & $90 \%$ & $10 \%$ & 100 \\
\hline
\end{tabular}

From the above findings, $90 \%$ of the respondents said that they believe that bancassurance has a very bright future because there is an immense potential for the insurance industry in India. But $10 \%$ believe that due to the emergence of the new technology the visits in the branches are going to be less because of ATM's and e-banking. So there is not much scope for it.

Future of Bancassurance

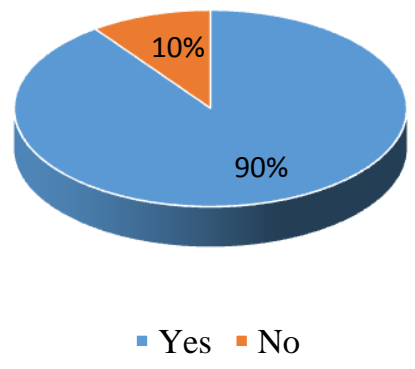

\section{ISSUES AND PROBLEMS OF BANCASSURANCE}

The following are the problems or issues faced by bancassurance industry in India:

- The change from manufacturing to pure distribution of insurance requires banks to pull together the incentives of different suppliers with their own products in a more improved way.

- Bank employees are usually low on enthusiasm. Lack of sales culture itself is a big barrier than the lack of marketing skills in the employees. Banks are generally used to only product packaged selling and hence selling insurance products logically do not seem to fit in their system.

- Private sector insurance firms are finding 'change management' as a major challenge. A public sector bank frequently gets a new chairman almost every two years from different bank. This results in an absolute change in the distribution strategy and further creates dissimilarity between public and private sector banks

- The banks also fear that at some point the insurance partner may end up cross-selling banking products to their policy holders. If the insurer is selling the products by agents as well as banks then there is a risk of clash between both if the agents targeting the same customers

\section{Findings AND SUGGESTIONS}

- Under HDFC Standard Life Insurance Co. Ltd. It earned a huge commission income of Rs. 534 crores in the year 2009-10 and Rs. 670 crores for the year 2010-11. During the year 2011-12, the income from life insurance business decreased significantly to Rs. 456 crores from Rs. 670 crores in previous year. In the year 2012-13 the bank recorded a commission income of Rs. 472 crores.

- In the year 2009-10, Under HDFC Ergo General Insurance Co. Ltd., bank's commission income increased to Rs. 54 crores and increased to Rs. 78 crores in the year 2010-11. In the year 2011-12, the bank recorded a commission income of Rs. 110 crores and Rs. 126 crores for the year 2012-13.

- In the year 2009-10, under bancassurane, Canara Bank earned a huge commission income of Rs. 8 crores and Rs. 11 crores for the year 2010-11. In the year 2011-12, the bank recorded a commission income of Rs. 12 crores and Rs. 13 crores for the year 2012-13.

- During the year 2011-12, income from life insurance business of Canara bank dropped down to Rs. 26 crores from Rs. 51 crores in previous year. In the year 2012-13 the bank recorded a commission income of Rs. 26 crores.

- $60 \%$ of the respondents were aware that their banks provide bancassurance .But still few people do not know about bancassurance as a concept. The employees of the banks must be given appropriate training to sell insurance products so that they can respond to any queries of the clients and can supply them with products according to their needs.

- Among the respondents who were surveyed, there were only $69 \%$ of the customers who had taken insurance policy from their respective banks. Remaining $31 \%$ did not opt to take a policy from their banks.

- $95 \%$ of Customers have abundance of trust on the banks and because of this reliance the customers may obtain insurance products from banks. Banks and insurance companies should improve the products frequently according to the needs of the customers.

- It is observed that $32 \%$ customers preferred agents because they provide personalized services. $30 \%$ took insurance from companies because of their trust on the company. 29\% said they would buy insurance from banks because of the brands name and their trust on banks. Only $9 \%$ said that they would buy insurance from brokers.

- It has been observed that almost all the customers are availing insurance products from the banks. The highest usage rates are for vehicle and life insurance products.

- It is observed that advertisements are one of the major sources of information for the customers. Better 
trained bank employees as well as the informative marketing techniques can give boost to the business.

- $90 \%$ of the respondents said that they believe that bancassurance has a very bright future because there is an immense potential for the insurance industry in India. But $10 \%$ believe that due to the emergence of the new technology the visits in the bank branches are going to be less because of ATM's and e-banking. So there is not much scope for it.

\section{CONCLUSION}

The insurance industry in India has been progressing at a rapid speed since the inception of this sector. There is a bright future for bancassurance in the Indian insurance market. Growth rate of insurance income is remarkable in some of the banks so there is very good scope for further development in the selling of bancassurance products by the banks in the long run. We can conclude that bancassurance is gaining recognition in the market

\section{REFERENCE}

[1] Dr. Sumathi Kumaraswamy, "Bancassurance: Tapping of Insurance into Banking Pursuit" International Journal of Scientific and Research Publications, Volume 2, Issue 7, (P1- 5) ISSN 2250-3153 July 2012.

[2] Anuja Banerjee, "Bancassurance: A Major Para-banking Activity", Insurance Chronicle, Pp. 35-38. Apr. 2009.

[3] Nalini Prava Tripathy. "Bancassurance in India-Tasks Ahead", Journal of Insurance and Risk Management, Vol.V, Issue 10, Pp. 51-60, June 2007.

[4] Malpani, Sudarshan, "Many roads to Bancassurance", IRDA Journal, Aug 2003.

[5] Neelamegam, R. and Veni, K. Pushpa, Bancassurance - "An Emerging Trend in Indian service Sector", Indian Journal of Marketing, Pp 50-54, October 2009.

- $\quad$ www.irda.gov.in

- www.google.com

- www.banknet.com

- $\quad$ www.insuremagic.com

- $\quad$ www.hdfcbank.com 